\title{
THE STRUCTURE OF CLASSIFICATION AND RANKING IN THREE HIGHLAND MAYAN COMMUNITIES ${ }^{1}$
}

\author{
by Victoria REIFLER BRICKER \\ Tulane University
}

The complementary terms bankilal and 'i申'inal are applied by the people of Zinacantan, Chamula, and Chenalho to a number of domains of their experience: kinship, religious and political social roles, physical objects, and natural features of the landscape. The contrast between bankilal and 'ic'inal seems to be fundamental to the thought of the Indians living in the three communities. Here the logical implications of this contrast will be explored.

The terms are difficult to define empirically in general terms; their meanings seem to be contextually determined. I submit that the terms belong to what might be called the ethical language of these communities rather than to a natural or empirical language and that any empirical definition will fall short the "true" meaning of the terms.

\section{Ethnographic Background}

Zinacantan, Chamula, and Chenalho are neighboring Mayan communities situated in highland Chiapas. Mexico, not far from the town of San Cristóbal Las Casas. The inhabitants of all three communities speak dialects of the Tzotzil language.

1 The data on which this paper is based were provided by six informants from Zinacantan, five informants from Chamula, and two informants from Chenalho. The fieldwork was supported by NIMH Pre-doctoral Fellowship MH-20,345, the Harvard Chiapas Project directed by Professor Evon Z. Vogt, and a grant from the Harvard Graduate Society. I am deeply gtateful to these institutions for their generous support which made the research possible. Special thanks go to Dr. Nicholas C. David, who suggested the approach I used in obtaining the data for this paper. I am also grateful for helpful comments and cristicism made by Professor Evon Z. Vogt, Dr. Gary H. Gossen, and Robert F. Wasserstrom. 
The population of Zinacantan in 1960 was 7650 persons (Cancian 1965: 7). By now it must have increased to about 9000 inhabitants (Vogt, personal communication). Gossen (1970: 57) estimates the population of Chamula as approximately 40000 persons. The population of Chenalho in 1961 was 5500 persons (Guiteras-Holmes 1961: 8). Most Indians in the highlands of Chiapas live in widely dispersed hamlets. Chamula, Chenalho, and Zinacantan comprise distinct political units called municipios by the Mexican government which Cancian (1965: 7) suggests are equivalent to townships. Each township has a ceremonial and political center called bteklum where the principal churches, town hall, a school, a medical clinic, and some small shops are located.

In Zinacantan the important political and religious units are the township and the hamlet. Chamula is divided into three wards, called barrios, each of which has its own patron saint from which the barrio takes its name: San Juan, San Pedro, and San Sebastián. Each barrio has its quota of political officers in the town government and religious officials in the religious organization. Chenalho was formerly divided into endogamous upper and lower sections corresponding approximately to the southern and northern halves of the community, respectively, which were equally represented in the political and religious bodies (Guiteras-Holmes 1961: 64-65). There are no longer such endogamous geographically based groups in Chenalho, nor do geographic considerations enter into the recruitment of political and religious officers.

The highlands of Chiapas are inhabited by two major ethnic groups: Ladinos and Indians. "Ladinos are persons who wear European clothes and speak Spanish as their principal languages (although their ancestors may be Indians)" (Cancian 1965: 7n). Historically, relations between the two groups have been hostile.

"Ladinos in general look down on the Indians, accuse them of witchcraft and speak derisively of their customs and beliefs while trying to make the best of them in commercial transactions" (Guiteras-Holmes 1961: 23).

Many Ladinos view Indians as uncivilized, dirty, and uneducables. Indians, for their part, regard Ladinos as exploitative and aggresive; they associate Ladinos with the Devil in their myths and dreams. Some years ago the inhabitants of Chamula expelled their resident Ladino population from the township and to this day permit no Ladinos to live within the boundaries of the township with the exception of the priest, some school teachers, and the secretary in the town 
government who, by Mexican law, must be a Ladino (Gossen 1970: 71). Zinacantan and Chenalho support small Ladino populations in their ceremonial centers. Only about 50 Ladinos lived in Zinacantan Center in 1960.

The traditional occupation for men in all three communities is maize agriculture. In Chamula the mainland ratio does nort permit all men to make their living by farming. Many Chamulas supplement their farm incomes by hiring themselves out to work on the land of wealthier members of the community or of Zinacantecos. Some Chamulas support themselves by engaging in the manufacture of pottery, musical instruments, ceremonial robes, and charcoal which they sell to Indians in other communities and, in the case of pottery and charcoal, to Ladinos.

The town governments in the three communities are headed by men called presidente and include sindicos, regidores, jueces, and mayores. In Chamula and Chenalho, but not Zinacantan, there are officials called alcaldes and gobernadores. The position of mayor cabildo exists uniquely in Chamula and the position of alguacil is today peculiar to Chenalho. In the past, however, there were alguaciles in Zinacantan who functioned as tax collectors (Zabala 1961: 148). The presidente serves as the mayor of the township and is the principal link between the Mexican government and the Indian community. He also takes a leading role in mediating legal disputes. In Zinacatan the sindico is like a vice-mayor who substitutes for the presidente when he is absent. In Chamula the ranking alcalde is the president's alternate; the sindico takes care of collecting taxes in the market. In Chenalho "the sindico, in actual practice, is the president's assistant and generally accompanies him" (Guiteras-Holmes 1961: 80 ), but it is the gobernador who takes the president's place in his absence (Guiteras-Holmes 1961: 80). Gobernadores in Chamula look after the church. The jueces are judges who play a role in settling disputes. Regidores in Zinacatan have no special responsibilities; in Chenalho the regidores are in charge of the ritual aspects of political life, bearing standards in all religious ceremonies, determining which men to appoint to office, and swearing them in on New Year's Day (Guiteras-Holmes 1961: 81). Those duties are assumed by the mayor cabildo in Chamula. In Chenalho the alcaldes are in charge of social welfare. "They are spiritually and materially responsible for the respect due to life and limb" (Guiteras-Holmes 1961: 80). The alcaldes of Chamula collect the taxes which are used to pay the salary of the Ladino secretary. Mayores in all three communities (together 
with the alguaciles in Chenalho) constitute the township's police force. In addition they serve as messengers for all the other political officers and they are the ones who are sent to fetch people who have been accused of crimes to stand trial. Some important auxiliary members of the political organization are the escribanos or scribes who are responsible for keeping records and writing official correspondence.

In Chenalho the political and religious offices in the community are arranged in a single hierarchy of nine levels. There are two levels of religious cargos sandwiched between seven of political positions. In Zinacantan and Chamula the political and religious hierarchies do not interlace as they do in Chenalho. With one exception (see Vogt 1969: 272), service in political offices in Zinacantan does not count for progression up the religious hierarchy and vice versa. Similarly in Chamula the political hierarchy is an independent entity, however, unlike Zinacantan, religious offices in Chamula are not arranged in a hierarchy. Instead the cargos are distributed among two independent cults. There is no prescribed order which Chamulas follow in taking religious cargos. Typically they take the most expensive cargos they can afford.

Religious cargoholders in Chamula and Chenalho are called alféreces and mayordomos. In Zinacantan a man begins his cargo career by taking a cargo on the mayordomo level, continues with cargos on the alférez and regidor levels, and concludes with a cargo on the alcalde level. In all three communities mayordomos and alféreces are responsible for the care of, and ceremonies in honor of the saint images in the churches. Cargoholders take turns sponsoring fiestas in honor of the saints.

Shamans ( $b^{2}$ iloletik) comprise the third sector of public life in the theree communites. The chief means of recruitmen is by dreams; shamans learn of their calling in a series of dreams in which they see native deities who live inside the mountains. Zinacanteco shamans are organized in a formal hierarchy based on length of service. A boy who made his debut at fifteen is ranked higher than a man who received the call at forty. Although this ranking of shamans is always recognized in relation between shamans, the frequency with which a shaman is asked to perform private ceremonies depends more upon his reputation for success than upon his rank. The shamans of Chamula and Chenalho are also ranked in terms of length of service but their organization seems to be less formal than in Zinacantan.

Each Zinacanteco, Chamula, and Pedrano ${ }^{2}$ has two souls:

2 The term "Pedrano" is commonly used to refer to inhabitants of San Pedro Chenalho. 
with the alguaciles in Chenalho) constitute the township's police force. In addition they serve as messengers for all the other political officers and they are the ones who are sent to fetch people who have been accused of crimes to stand trial. Some important auxiliary members of the political organization are the escribanos or scribes who are responsible for keeping records and writing official correspondence.

In Chenalho the political and religious offices in the community are arranged in a single hierarchy of nine levels. There are two levels of religious cargos sandwiched between seven of political positions. In Zinacantan and Chamula the political and religious hierarchies do not interlace as they do in Chenalho. With one exception (see Vogt 1969: 272), service in political offices in Zinacantan does not count for progression up the religious hierarchy and vice versa. Similarly in Chamula the political hierarchy is an independent entity, however, unlike Zinacantan, religious offices in Chamula are not arranged in a hierarchy. Instead the cargos are distributed among two independent cults. There is no prescribed order which Chamulas follow in taking religious cargos. Typically they take the most expensive cargos they can afford.

Religious cargoholders in Chamula and Chenalho are called alféreces and mayordomos. In Zinacantan a man begins his cargo career by taking a cargo on the mayordomo level, continues with cargos on the alférez and regidor levels, and concludes with a cargo on the alcalde level. In all three communities mayordomos and alféreces are responsible for the care of, and ceremonies in honor of the saint images in the churches. Cargoholders take turns sponsoring fiestas in honor of the saints.

Shamans ( $b^{2}$ iloletik) comprise the third sector of public life in the theree communites. The chief means of recruitmen is by dreams; shamans learn of their calling in a series of dreams in which they see native deities who live inside the mountains. Zinacanteco shamans are organized in a formal hierarchy based on length of service. A boy who made his debut at fifteen is ranked higher than a man who received the call at forty. Although this ranking of shamans is always recognized in relation between shamans, the frequency with which a shaman is asked to perform private ceremonies depends more upon his reputation for success than upon his rank. The shamans of Chamula and Chenalho are also ranked in terms of length of service but their organization seems to be less formal than in Zinacantan.

Each Zinacanteco, Chamula, and Pedrano ${ }^{2}$ has two souls:

2 The term "Pedrano" is commonly used to refer to inhabitants of San Pedro Chenalho. 
1) an inner personal soul called č́ulel and 2) an animal alter-ego called $\check{\mathbf{c}}_{a n u l}$ in Zinacantan, $\check{\mathbf{c}}^{\prime} u l e l$ in Chamula, and waybel in Chenalho (Guiteras-Holmes 1961: 139-140). The Zinacanteco acquires his "animal spirit companion" (Vogt 1965: 34) at birth; when the ancestral deities

"... install a ch'ulel / č'ulel/ in the embryo of a Zinacanteco, they simultaneously install the same ch'ulel in the embryo of an animal. Similarly, the moment a Zinacanteco baby is born, a jaguar, coyote, ocelot or other animal is born. Throughout life, whatever happens of note to the Zinacanteco happens to his chanul / ̌́anul/ and vice versa" (Vogt 1965: 34).

No information is available from Chamula and Chenalho concerning beliefs about the relationship between the personal and animal souls.

\section{The Syntax of Bankilal/'Il'inal Terms}

The terms bankilal and 'id'inal may be used as nouns or adjectives in all three communities. Their chief use as nouns occurs in the kinship domain. Bankilal refers to "older brother of male speaker" in Zinacantan and "male older sibling/cousin of male speaker" in Chamula and Chenalho. Similarly, the noun 'iç'inal refers only to "younger brother of male speaker" in Zinacantan but also to "younger male cousin of male speaker" in Chamula and Chenalho. The nouns bankilal and 'ie'inal are used exclusively to refer to social personages. In non-kinship domains they may be glossed as "senior" and "junior" respectively (Vogt 1969: 239).

The suffix - $a l$ in the nominal terms bankilal and 'i i'inal indicates that these nouns are in their absolute or abstract form. When used in reference to express concrete kinship relations, the noun stems - bankil and - i $\phi^{\prime}$ in appear with possessive prefixes: $b-\sim$ $k-$ ("my"), $a-\sim a v-$ ("your"), $s-\sim y-$ ("his, her, its"). Address terms in Zinacanteco Tzotzil take neither possessive prefixes nor the absolute suffix. In the dialects of Tzotzil spoken in Chamula and Chenalho, some address terms are homonymous with their reference counterparts. However, the address terms may denote a greater range of kin types than their reference homonyms. For example: 
"Chamula female speakers may use bbankil to address their older male siblings (and cousins), just as they may use ki申'in to address their younger male siblings. This however does not apply to terms of reference; in this case they use the regular term for female speakers / $b$ šibel 'male older sibling/cousin of female speaker', bmuk 'younger sibling/cousin of female speaker'/" (Gossen, personal communication).

As adjectives the terms appear in two linguistic environments: 1) in compound proper names such as martomorey bankilal (bankilal mayordomo rey) and 'iф'inal san hose ('iф'inal St. Joseph statue); 2 ) in the comparative expressions mas bankilal (more bankilal) and mas 'i申'inal (more 'ic'inal). When the noun in question is understood, the adjective may stand alone. For example:

\section{mi tal ša li bankilal mastaroe?}

Did the senior musician come? $m u^{2}$ yuk to, pere talem $\check{\mathrm{s}}_{a} l i{ }^{2} i \varphi^{\prime}$ 'inale.

Not yet, but the junior (musician) has already come.

(Gossen, personal communication)

The grammatical distinction between noun and modifier has its cognitive correlate: the difference between the process of classification and the process of ranking. In all three communities the nominal terms bankilal/Pie'inal are used to classify phenomena while their adjectival homonyms are used to rank phenomena or classes of phenomena. The adjectival terms are used to evaluate phenomena previously classified in terms of empirical criteria but evaluatory terms, strictly speaking, belong to ethical discourse, not empirical discourse. The evaluatory meaning of bankilal is "better" and of 'ic'inal is "worse". In other words, evaluation in terms of the bankilal/Piф'inal contrast represents a second stage in the process of segmenting experience, the first stage being the construction of folk taxonomies.

A classificatory term is the name of a distinct class or category consisting of a set of members which share values of one or more criterial attributes. For every value shared by the members of that class there exists at least one other class on the same taxonomic level of the hierarchy, which is defined in terms of the same criterial attribute, but with a different value.

Where a classificatory term groups elements into a class on the basis of some attribute value which they share, ranking terms dif- 
ferentiate members within that class in terms of some other criterial attribute. Classification and ranking may thus be viewed as principles operating on two different axes which intersect at right angles. In the two-dimensional diagram in Figure 1 , the $\mathrm{Y}$-axis represents the axis of classification and the $\mathrm{X}$-axis the axis of ranking. On the $\mathrm{Y}$-axis one pole represents the general and the other the specific. Along the $\mathrm{X}$-axis, with positive evaluation at one pole and negative evaluation at the other, elements on any taxonomic level of the Y-axis are ordered from 1 to $\mathrm{n}$.

It is clear that classification is logically prior to ranking because it determines the boundaries of the contexts in which ranking occurs. The boundaries are defined by the values of the critierial attributes shared by the members of the class wich may be differentiated by ranking.

Since ranking is an operation performed on previously classified material, the structure of ranking is dependent on the structure of classification which it orders.

A list of the values of the criterial attributes which distinguish one class from all other taxonomically equivalent classes is known as the "componential definition" of the term which labels that class. Componential definitions of terms are "context-specific"-they are defined in terms of one level of one taxonomic hierarchy only. Therefore the "cluster" of value-components which make up such a definition do not correspond to the "multiple meanings" of the terms for "multiple" is generally understood to mean different meanings in different contexts as well as different meanings in the same context. For each context a new componential definition would be necessary.

Since ranking principles operate at right angles to classificatory schemes, ranking terms are not restricted in application to only one level of a taxonomic hierarchy. In the case of bankilal/Piф'inal ranking, the terms may be used on different levels of the hierarchy with different attribute values on each level. If the structure of bankilal/Pid'inal ranking within that taxonomy is to be understood, it is necessary to consider the attribute values of the terms in several contexts (i.e., different taxonomic levels). The definitions of bankilal and 'ic'inal in that hierarchy context will be lists of several attribute-values. The definitions, although phrased in terms of criterial attributes, are not componential definitions because they are not restricted to one context and because they do not define terms which name classes. 
In the kinship domain the nouns bankilal and 'ip'inal are defined in terms of five dimensions or criterial attributes (only four dimensions in Chamula and Chenalho): 1) age relative to ego (older/ younger), 2) relative sex of speaker and referent (male-male female-female/male-female/female-male), 3) generation $(0 /+1 /+$ $2 /-1 /-2), 4)$ consanguineal/affinal, 5) lineality (lineal/collateral). They differ in only one attribute: age relative to ego. The values of attributes 2-5 (male-male, zero generation, consanguineal, lineal) together yield the componential definition "brother of male speaker" (in Zinacantan), and the values of attributes $2-4$ yield the componential definition brother/male cousin of male speaker" (in Chamula and Chenalho).

It is obvious that since the criterial attributes used to define classes cannot be the same as the attributes used to rank members within classes, the adjectival terms bankilal and 'ic'inal will not mean "older brother of male speaker" and "younger brother of male speaker" nor "older male cousin of male speaker" and "younger male cousin of male speaker" respectively. In the kinship domain when mas bankilal and mas 'i ipinal are used to rank members within the covert category "brother", the relevant criterial attribute is not age relative to ego but age relative to all other members of the class (ego is a member of the class). Thus mas bankilal in this context has the value "older" but not "older brother of male speaker" and mas "il'inal has the value "younger" but not "younger brother of male speaker". The oldest brother is most bankilal, the youngest is most 'i申'inal, and all other brothers would be ranked from 2 to $n-1$ (see Figure 2). However, normally Zinacantecos, Chamulas, and Pedranos group brothers into three classes: bankilal, 'i $\phi^{\prime}$ 'inal, and the class containing only ego (see Figure 3 ). When the individuals within the kinship classes "older brother" (bankilal), "younger brother" ('ic'inal) are ranked in terms of mas bankilal and mas 'ich'nal, the oldest in each class is most bankilal, the youngest in each class is most 'i申'inal, and the rest of the members in each class are ranked from 2 to $\mathrm{n}-1$. On the other hand, if the classes (as opposed to the members of the classes) bankilal, 'if'inal, and ego are themselves ranked in terms of each other, the bankilal class is ranked as mas bankilal and the 'iф'inal class as mas 'i申'inal (Figure 3 ). The class containing ego as its only member would be ranked as more bankilal than the 'i申'inal class and more 'i申'inal than the bankilal class. In Chamula and Chenalho the covert category in question could be "male sibling/cousin" instead of "brother". 
Although the nouns bankilal and 'if'inal in the kinship domain refer only to male relatives in ego's generation, ego may use the comparative expressions mas bankilal and mas 'ic'inal to rank relatives between generations or relatives within the first and second ascending or descending generations. Nor need the terms be restricted to male relatives; they may be used to rank sisters, or to rank mothers, sisters, daughters, and grandmothers in relation to each other. Grandmothers are more bankilal than mothers, mothers are more bankilal than sisters, and daughters are more 'ic'inal than mothers, grandmothers, and aunts. Similarly, grandfathers are more bankilal than fathers, fathers are more bankilal than ego or his brothers, and sons are more 'i申''inal than fathers, uncles, and grandfathers. In all these cases bankilal has the value "older" and 'i i'inal has the value "younger". On the other hand, when male relatives are compared with female relatives, male relatives rank higher than female relatives. In terms of such comparisons, bankilal has the value "male" rather than "older", and 'ic'inal has the value "female" rather than "younger". What this means is that men have higher status than women and older people enjoy higher status than younger people. Thus the bankilal/'ic'inal contrast is not just a contrast between male/female or older/younger, but it is an evaluation in terms of higher and lower status, the criteria for this ranking in the kinship domain being age and sex. The interaction of two or more variables or parameters in any single domain will be discussed later in this paper.

\section{Domains of Bankilal/'Ié'inal Ranking}

The adjectives bankilal and 'iो'inal seem to apply only to phenomena that are socially or religiously meaningful and only to those aspects of objects which have social or religious significance. For example, in Zinacantan tables, chairs, and houses as such are not ranked in terms of bankilal and 'i申'inal; they are distinguished only in terms of size: muk'ta (large) or bik'it (small), but large objects are not necessarily evaluated as better or worse than small objects. However, the orientation of tables has bankilal/'id'inal significance because the four cardinal directions are meaningful religious symbols as is the distinction between left and right. The designation of an end of a table as its head or foot depends on its east-west orientation; since east is bankilal in relation to west, the head of 
the table (shol meša, sba me $a$ ) is its eastern end and the foot of the table (yok meša) points to the west. Therefore the head of the table is more bankilal than the foot. Similarly, the fact that south is more bankilal than north means that the southern side of the table is more bankilal than the northern side (bankilal bot mešal 'i申'inal bot meša). When seated at the table, the most bankilal person sits at the head (east) on the southern side; his social inferiors line up in descending order of importance on his left and across the table from him (see Figure 4). In Chamula where color symbolism is an important parameter of bankilal/'iф'inal contrast, green tables are more bankilal than white tables.

In all three communities bankilal/Piф'inal terms do not apply to rivers, stones, mountains, caves, or waterholes unless those natural features are given proper names and have crosses erected beside or on top of them. The crosses transform natural features into religious shrines, making them objects of cultural significance and therefore eligible for bankilal/'ic'inal ranking.

Women in the three communities are not of great social or religious importance. They typically do not participate in public life in their own right but only as the consorts of their husbands. Women are usually ranked in terms of their husbands' roles as "wife of the bankilal _— " and "wife of the Piф'inal _Wife" is yabnil in Zinacantan and $m e^{\text {? }}$ in Chamula. Thus yabnil martomorey 'it'inal means "wife of the 'i申'inal (junior) mayordomo rey" and $m e$ ? Palkalte bankilal means "wife of the bankilal (senior) alcalde". One public role in Zinacantan is assumed exclusively by women. There are two hpat vab ("tamale makers") who are responsible for making tamales at weddings; they are called bpat vab bankilal and hpat vah 'iф'inal.

There is essential agreement among informants from the three communities that civil officials, religious officials, ritual assistants, saints, ritual paraphernalia such as musical instruments and fireworks, shamans, sacred places marked by cross shrines and "animal spirit companions" (Vogt 1965: 34) may be ranked in terms of the bankilal/'ic'inal contrast. But the initial classification of some domains varies from community to community. Chamula is divided into three barrios, each of which is represented separately in the town government and the religious organization. There are no such geographic divisions in Zinacantan and Chenalho at present, although there is some evidence that Chenalho was once divided into two sections, which like in present-day Chamula, were equally repre- 
sented in the political and religious bodies of the town (GuiterasHolmes 1961: 64-65). There are corresponding differences in bankilal/'ic'inal ranking among the three communities.

Even when the categories of classification are equivalent in some domain, there may be differences in the number of items which the categories in question contain. As will be shown in the next section, the structure of bankilal/'ip'inal ranking is as much affected by the number of members a set or class contains, as it is by the particular distribution of classes within a taxonomy.

\section{Types of Bankilal/P'č'inal Ranking}

Within each of the three communities several different types of bankilal/'i申'inal ranking occur. A taxonomic class may consist of one member, two members, or more than two members. In no community is the bankilal/'ie'inal contrast applied to a class containing only one member. Obviously ranking is an operation performed on a set of two or more elements. This does not preclude the class of only one member being ranked as a class against other classes on the same level of the taxonomic hierarchy as was the case with the class containing only ego in Figure 3.

Classes containing two members are ordered in only one way: one member is evaluated as bankilal or mas bankilal and the second as 'ic'inal or mas 'i申'nal. For example, the class of religious officials in Zinacantan called martomorey (mayordomo rey) contains only two members: martomorey bankilal and martomorey 'i $i$ 'inal. The bankilal/'i 'inal ranking applied to classes containing only two members will be called a paired contrast. Classes containing more than two members may be ranked in several ways: as series, ranked pairs, or orders.

Series. A series consists of elements more than two in number which are ranked from 1 to $\mathrm{n}$. There are four kinds of series:

1. The first member of the series is called bankilal and all the rest are called 'ip'inal. This is the bankilal/Pi' inal series ranking pattern characteristic of Chamula and Chenalho.

2. The first member of the series is bankilal, the last member is 'i 'inal and the members in between are numbered from 2 to $\mathrm{n}-1$. This is the characteristics pattern of series ranking in Zinacantan.

3. In Chamula when a series consists of four items, the first is bankilal, the last is 'i $i$ 'inal while the second may be called ' 0 ?lol 
bankilal (half bankilal) and the third 'o'lol 'id'inal (half 'i i'inal).

4) The first member of the series is designated bankilal and the other members are ranked from 2 to $\mathrm{n}$. This is an alternative pattern in Zinacantan and Chamula.

Ranked pairs - Within a domain, the members are grouped into pairs with each member of each pair ranked in terms of bankilal and 'i申'inal. These bankilal/'ic'inal pairs may themselves be ranked in terms of each other from 1 to $\mathrm{n}$. For example, in Zinacantan there are twelve mayordomos grouped into six bankilal/'i申'inal pairs. Each pair is responsible for a different saint. The six sets of mayordomos are ranked from 1 to 6 : the mayordomos of the Virgin of Rosario are regarded as the most bankilal and the mayordomos of San Antonio as most 'i i''inal.

The interplay of these two degrees of bankilal/Pi'inal ranking is diagrammed in Figure 5. Ranked pairs are essentially combinations of pairs and series.

Orders - A group of elements is first divided into two bankilal/ 'if'inal subgroups or orders. Within each order the first element is bankilal and the last is 'ic'inal; the rest of the members range from 2 to $\mathrm{n}-1$. The arrangement within an order is like that of a series. Shamans in Zinacantan are organized in this way (Figure 6). Orders differ from ranked pairs in the sense that there is no between-series pairing of members (compare Figure 6 with Figure 5).

\section{Criteria of Bankilal/'I' 'inal Ranking}

It is convenient to view the criteria of bankilal/Píp'inal ranking as parameters, each of which has two values. The term bankilal corresponds to one of the values and the term 'i申'inal corresponds to the other. If the criteria are continuous variates, the members of a set may be ranked from 1 to $\mathrm{n}$ from highest to lowest or lowest to highest, depending upon which ends of the spectrum the terms bankilal and 'i申'inal are assigned to. Size and age are examples of parameters which are continuous variates. Larger objects may be more bankilal than smaller objects and older people are more bankilal than younger people. Discontinuous variates may be arranged in series or they may be grouped into orders, the group with one value being bankilal and the group with another value being 'i $i$ 'inal. Sex is an example of a parameter which is a discontinuous variate. If a class contains only two members, one of each sex, the male would 
outrank the female. On the other hand, a class containing more than two members of one or both sexes would be divided into two orders, one male and the other female. Some parameters of bankilal/ $i \psi^{\prime}$ 'inal ranking in the three communities, together with their associated values, are presented in portmanteau fashion in Table 1.

Age, sex, size, distance, height, elevation, time, power, knowledge, and intelligence are parameters of bankilal/Pie'inal ranking in all three communities. Color seems to be an important parameter in Chamula but not in Chenalho or Zinacantan. The bankilal/'id'inal ranking of barrios is peculiar to Chamula.

In many domains, several parameters interact in the bankilal/ 'ic'inal ranking of elements and/or classes in those domains. In such case, one parameter takes priority over the other-the parameters used in ranking are themselves ranked! The interaction of the parameters, sex and age, in the kinship domain has already been noted. In formal contexts the sex parameter outranks age: men and women form separate orders within which they are ranked in terms of age. Thus in a drinking ceremony the drink-server begins with the eldest man present, continues with the next oldest man, and serves the youngest man before he begins to serve the oldest woman. The youngest woman present is, of course, served last. On the other hand, if a young man meets an older man or woman on the trail, he will bow to each of them. The sex parameter is not operative in informal contexts of this sort.

Several parameters may be inferred from the seating order which is observed at the table. In Zinacantan the most bankilal position at the table is at the eastern end on the southern side. The second most bankilal position is also at the eastern end, but on the northern side (Figure 4). No one sits to the right of the most bankilal person; many of his social inferiors sit to the right of the next most bankilal person. Clearly the parameter with the values east/ west takes precedence over the parameter with the values right/left. Chamulas seat themselves according to the same rules (Gossen 1970:459). In Chenalho, where tables are oriented in a north-south direction, with the head pointing south (Guiteras-Holmes 1946:124), the relevant dominant parameter is south/north rather than east/ west.

Age and sex are the chief determinants of seating order in the private sector. When both men and women sit at the table, the oldest male present takes the most bankilal position. The men are grouped near the head of the table and the women sit nearer 
the foot of the table. In public life, however, age and sex are not the significant determinants of seating order. First of all, women usually do not take part in public meals. Secondly, the relevant parameters are usually different for each group of functionaries. Civil authorities are ranked in terms of their authority and authority seldom correlates directly with age. ${ }^{3}$ The presidente, who gives orders to the rest of the officials, sits in the most bankilal position. The mayores and/or alguaciles sit at the foot of the table because they take orders from everyone ranked above them. In Chenalho the presidente sits at the very head of the table, flanked by the sindico on his right and the gobernador on his left. Along the sides of the table sit the alcaldes, regidores, mayordomo rey, mayores, and alguaciles - in that order. The presidente of Chamula occupies the most eastern position on the south side of the table. After him, from head to foot, are the alcaldes, scribes, mayor cabildos, gobernadores, sindicos, and mayores. In Zinacantan the seating order is: presidente, sindico, jueces, and mayores.

Within each category of civil office the men are ranked in terms of how much responsibility they are charged with. There is only one presidente in each town. In Chenalho there are two alcaldes and five regidores. The alcaldes are differentiated as bankilal and 'i $i$ inal. The first regidor

"... is called bankilal regidor or regidor mayor, and the others are second, third, fourth, fifth, or kox $\left\{k^{\prime} \circ \mathrm{s}^{\prime}\right\}$. Their rank and prestige are the same, but the bankilal apparently leads the others. The bankilal is generally selected on the basis of his knowledge and command" (Guiteras-Holmes 1961: 81-82).

In Chamula, as in Chenalho, the presidente outranks all civil officials. But in Chamula authority and responsibility are not the only parameters cited in ranking civil officials. Another parameter is barrio affiliation. For example, the alcaldes representing the barrio of San Juan outrank those from San Pedro who, in turn, outrank those from San Sebastian. Within each barrio the civil officials in the categories alcalde, gobernador, mayor cabildo, sindico, and mayor are ranked from 1 to $n$ in terms of responsibility. The first is always bankilal and the rest, who are all mas 'i $\phi^{\prime}$ 'inal, are ranked from second to nth.

\footnotetext{
3 In the past, authority probably varied directly with age. Today young men are recruited to positions of political authority because they are more apt to be bilingual than older men are and because, in order to deal effectively with the Ladino world, the higher-ranking civil officials must be able to speak Spanish.
} 
The ranking of religious officials in the three communities is determined by how many times they have taken cargos and the cost of their cargos. In Chenalho the men chosen for the bankilal positions are those whom the elders think would be most capable of performing the requisite ritual; less capable men are selected for the 'it'inal positions. Today Zinacantecos volunteer for cargo positions, but in the past men were appointed to all positions by the elders (Cancian 1965: 25). Presumably, as is still the case in Chenalho, the men appointed to the bankilal positions were those thought to be the more capable, and those appointed to the 'i $i$ 'inal roles were thought to be less capable.

Religious cargoholders of the two lowest levels in Zinacantan are grouped into bankilal/'i申'inal pairs. There are also four regidores, ranked from 1 to 4 , and two alcaldes called muk'ta (great) and bik'it (little) (Figure 7). The muk'ta 'alkalte ranks higher than any $\operatorname{man}$ in the community. The bik'it 'alkalte ranks inmediately below him. Alfereces derive their bankilal/?ič'inal ranking from the importance of the saints they care for. The longer the saint figure has resided in the church, the more bankilal it is; newly acquired saint figures are mas 'i 'inal.

What determines the bankilal/'i申'inal ranking of mayordomos and alfereces in Chamula is the relative importance of the fiestas they sponsor. Lesser saints recive smaller celebrations and their sponsors are relatively more 'i $i$ ' inal. The highest ranking alfereces are the Passions (pašyon) and those called ničim. The Passions, who are the sponsors of the fiesta of Carnaval and Easter, outrank the ničim who are regarded as the "servants" of the Passions. Each barrio is represented by two Passions and two ničim. These cargoholders serve two-year terms of office, entering office on alternate years. Ranking within each category is determined by their barrio affiliation and by whether the man in question is in his first year of office ( $b^{2}$ očel "entering") or in his last year of office (blok'el - "leaving"). The outgoing official is more experienced and therefore outranks his incoming counterpart. The barrio ranking is the same as for civil officials. The barrios take turns recruiting men for the other alferez positions. The mayordomos represent the barrios of San Juan and San Pedro only. The mayordomos of barrio San Juan are bankilal and those of barrio San Pedro are 'iф'inal.

In Chenalho the group of alfereces who sponsor the fiesta of Carnaval, also called Passions, are divided into two orders: an incoming order $\left(b^{2} \circ \check{c}^{e l}\right)$ and an outgoing order (blok'el). Members of the out- 
going group are more bankilal because they are more experienced. There are four Passions in each order. The first is designated sves Passion (from Spanish, juez - "judge", but best glossed here as "expert") and the last is referred to as k'oš ("young" or "inexperienced"). The other two are called second sves and third Passions. Thus the most bankilal Passion is most expert in making arrangements for the fiesta; the second sves Passion is his second in comand. The saints are tended by one alferez apiece. The alfereces of San Nicholas and Santo Cristo are grouped as a bankilal/'i申'inal pair, with the alferez of San Nicholas the more bankilal. Of the alfereces of Rosario and San Francisco, the latter is the more bankilal. The bankilal/?ic'inal ranking of alfereces reflects the importance of the saints whose fiestas they sponsor. At least five other saints are sponsored by alfereces (Guiteras-Holmes 1946: 92), but their bankilal/'i申'inal ranking has not been determined. There are also eight mayordomos, two per saint (Guiteras-Holmes 1961: 95), assigned to the following saints: Santa Cruz, San Pedro, Our Lady of the Rosary, and the Immaculate Conception. "The first three saints are regarded as of higher status than the last" (Guiteras-Holmes 1961: 95), but apart from this general ranking their bankilal/'i申'inal evaluation is not known. When sponsoring a fiesta, the alferez chooses two men to be captains of the men who race horses in honor of the event; one is bankilal and the other is 'if'inal. The bankilal captain is the one who was chosen first.

Shamans in Zinacantan form two orders. The bankilal order sits on the south side of the table; the bankilal shaman occupies the first position on the eastern end. The 'i $i$ 'inal order of shamans sits on the north side of the table. The most bankilal shaman within each order sits nearest the head of the table, the most 'if'inal shaman sits nearest the foot, and the other shamans sit in rank order between these extremes. The ranking of shamans is determined by their length of service (not their relative ages): the person who has been shaman longest is most bankilal. Data are lacking concerning the seating order of shamans in Chamula and Chenalho; however, the parameter of shaman ranking is the same in the three communities (that is, in terms of length of service).

For Chenalho, where political and religious offices are combined in a single hierarchy, the relative ranking of political in relation to religious positions is not difficult to determine. The rank-order of all political and religious officers is as follows, from lowest to highest: "Alguacil; Mayor; Alférez of a lesser image, or Captain; Alférez of 
a greater image, or Paxon [Passion] de Carnaval; Regidor; Alcalde; Gobernador; Síndico; Presidente" (Guiteras-Holmes 1961: 75). Note that the civil and religious offices interlace in their ranking, with five civil offices ranking highest, followed by the two levels of religious cargos, and finally the mayores, civil mayordomo and alguaciles. Where shamans belong in the ranking system is as yet undetermined.

Informants from Chamula claim that shamans outrank all civil and religious cargoholders. Although political offices form a separate hierarchy, the relative ranking of civil and religious posts can be inferred from the order in which the officials are asked to participate in the Bell Dance ('ak'ot čilon) during the fiesta of Carnaval. In any barrio, the outgoing Passion is the first man chosen to wear the jaguar skin trimmed with sheep bells and to carry the flag which represents Christ. When he has finished dancing, the incoming Passion puts on the jaguar pelt and takes his place. $\mathrm{He}$ is followed in turn by the civil officials, one by one, in rank order, and then by the ničim, outgoing first, followed by the incoming ničim. The rank order of officials in the public sector of Chamula seems to be as follows: shamans, Passions, civil officials, other religious officials.

The relative ranking of Zinacanteco shamans, civil and religious cargoholders may be observed on June 24th during the ceremonies which honour the summer solstice (" $\mathrm{o}^{2} \mathrm{lol}$ babil - "half year"). The senior religious alcalde offers a meal at his house at which the following seating order is observed by the participants (Figure 8): at the head of the table, on the south side, in the most bankilal position, sits the senior religious alcalde. Directly across from him, on the north side, sits the junior religious alcalde. Then follow the shamans, the bankilal order on the south side of the table and the 'id'inal order on the north side. Next come the four regidores, two on each side of the table, followed by the presidente on the bankilal side and his alternate, the síndico, on the 'i申'inal side. At the foot of the table sit first, the two mayordomoreyes and then the two mesoneros. In general the seating order seems to be: officials of the top two levels of the religious hierarchy, shamans, civil officials, officials of the lowest level of the religious hierarchy.

However this generalization should be modified in the light of certain historical data. Before the turn of the century, the alcalde and regidor cargos were principally civil cargos (Cancian 1965: 23). In 1899 a new civil government headed by a presidente was installed (Cancian 1965: 20). The alcaldes and regidores thereby lost most of their civil functions and became primarily religious officials, having 
been left with chiefly ceremonial duties. Although today the seating order of public figures at the yearly summer solstice ceremony suggests that power is monopolized by religious officials, it seems likely that the traditional pattern in Zinacantan was more like that of Chenalho where the highest-ranking political officials seem to outrank even the Passions.

Each set of public functionaries is ranked internally by a different parameter, but the external ranking of sets is in terms of one parameter only, power. Cost and prestige of position are relevant only in the context of religious roles. Length of service is relevant only in the contexts of the religious cargo system and the organization of shamans. Power is the highest-ranking social parameter, for all public roles are ranked in terms of it. Within the religious domain length of service outranks cost or prestige of position, which in turn outranks age. Among shamans length of service outranks age. But within the civil hierarchy, authority outranks both length of service and age.

The ranking of parameters is seen most clearly in the Zinacanteco ranking of sacred places visited during curing ceremonies (Table 2). There are four relevant parameters: origin (God-made/man-made or natural/cultural), height (summit/base, Tzo. bol/yok), elevation (high/low or highland/lowland, Tzo. 'ak'ol/Polon), ${ }^{4}$ size (large/ small,Tzo. muk'ta/bik'it), sex (male/female, Tzo. vinik/Pand). Their relative ranking is made clear in the branching diagram of Figure 9.

The most important shrines in Zinacantan are located on mountain tops. The most bankilal sacred place of all is called bankilal muk'ta $v i \phi$, which is the largest and steepest mountain shrine in Zinacantan. The animal alterego of each Zinacanteco resides there. Five of the six mountain shrines have cross altars both at the summit and at the base; the shrines at their bases rank below the sacred waterholes of $y a^{2}$ abvil and ninab čilo? and the sacred rock formation, č'ul ton, which is the doorway to the Sacred Potato Patch ('isak'tik) (Vogt 1969: 379). $H^{\prime} \breve{c}^{\prime} u l m e^{2} t i k$ is a sacred mountain situated at a much lower elevation to the west of the other shrines; for this reason its summit ranks below the smaller shrines located at higher elevations. The churches are ranked in order of their size.

Comparable data on sacred places from Chenalho is nonexistent and from Chamula, incomplete. Tentatively four parameters of ranking may be inferred for Chamula: size, barrio affiliation, color, and distance from the ceremonial center. For example, the sacred mountain

- One might also include here the parameter east/west because it coincides with the highland/lowland dichotomy (Wasserstrom 1970: 74). 
Con te? $v i \phi$ ranks above other shrines because it is the largest, because it is green, and because it is situated in barrio San Juan. Ba š'ek'en ranks below don te $e^{\text {? }}$ iो because it is located in barrio San Pedro. Each barrio has its own mountain shrine called kalvario; the kalvario are ranked in terms of their barrio affiliation and in terms of their size. Sakil č'en is ranked below don te viф because it is located in Zinacantan. Size and distance from the ceremonial center seem to be parameters of higher priority than are barrio affiliation or color. The important color contrast in this context is between red and green. Much of the open unforested land in Chamula Center is heavily eroded and leached red. The red (unforested) areas are the areas of human habitation and are 'id'inal; the green areas are bankilal because they are reserved for shrines and cemeteries.

Thus each taxonomy of classification has at least two levels. The parameters which rank the elements in the two levels (classes in the case of the higher level; objects in the case of the lower level) may be the same or different. If the parameters are different, the parameter which orders the classes of the upper level will have priority over the parameter which orders the objects of the lower level. For example, in Figure 7 the parameter length of service has priority over the parameter prestige (usually cost) of cargo.

\section{Cognitive Implications}

It is tempting to view the reciprocal terms bankilal and 'ic'inal as a fundamental set of binary oppositions in terms of which the people of Zinacantan, Chamula, and Chenalho dichotomize their experience. But, in fact, these terms are often combined with ordinal numbers, and represent only the extremes of a continuum of evaluation, rather than discrete categories. The paired contrast is only one of several structural manifestations of bankilal/'i申'inal evaluation. Furthermore, these terms are used comparatively rather than absolutely to characterize phenomena as "better" or "worse" rather than as "good" or "bad".

Although the terms are used by the members of all three communities, there are striking differences in their application. The general domains to which the terms may be applied are similar, but the criteria used in a particular domain sometimes differ from community to community. The ranking of political and religious officials in Chamula differs markedly from the ranking of analogous sets of 
officials in Zinacantan and Chenalho. For example, in all three communities there is a religious position called Passion. In Zinacantan there are two Passion roles: one is bankilal and the other is 'i $i$ 'inal. The structure of bankilal/'ip'inal ranking in this case is that of a paired contrast, and the criterion of ranking is authority. In Chamula there are three sets of Passions corresponding to the division into three barrios. The three sets of Passions are ranked in terms of their barrio affiliation; the structure of bankilal/'id'inal ranking based on this criterion is that of a series. Passions of each barrio are ranked internally in terms of whether they are outgoing or incoming Passions. The relevant criterion in this respect is length of service and the structure is that of a paired contrast. Passions in Chamula are therefore ranked in terms of two parameters where those of Zinacantan are ranked in terms of only one, and the criteria of ranking are different in each community. Where in Zinacantan the structure is that of a paired contrast, in Chamula the structure is that of pairs ranked in a series.

There is a historical explanation for this difference in ranking structure. In the middle of the sixteenth century the Dominican friars "reduced" or concentrated the population of Chamula into three centers (reducciones) (Remesal 1964: II, 178). The modern barrios of Chamula may be survivals of these divisions (Gossen 1970: $60)$. Zinacantan seems to have weathered the colonial period as a single social, religious, and administrative unit.

In Chenalho the eight Passions are first grouped into incoming and outgoing orders, and within the orders they are ranked from 1 to 4 .

No religious cargoholder in Zinacantan serves for more than a year at a time. In Chenalho and Chamula some religious officials, notably the Passions, serve two year terms of office. Here again the explanation for the difference in terms of office may be historical, particularly since in both and Chenalho there are other sets of religious officials, such as the mayordomos and some of the alfereces, who serve only one-year terms of office and who are ranked in terms of their relative authority rather than whether they are incoming or outgoing officials.

Where historical explanations do not suffice is in the case of the differential characterization of series. The Zinacanteco views the terms bankilal and 'ic'inal as poles of a continuum along which elements are ranked in terms of better or worse. In Chamula and Chenalho all but the first member of a class must be designated 'i $\phi^{\prime}$ 'inal. The 
distinction is between good and worse, rather than better and worse. Thus where a series of classes or objects is concerned, the inhabitants of Zinacantan have a more highly differentiated conception of bankilal/'ic'inal evaluation than do the people of Chamula and Chenalho (see Table 3 ).

The inhabitants of the three towns employ certain criteria of relevance in their use of the bankilal/'id'inal distinction. Even within an appropriate domain, not all elements within that domain are equally susceptible to bankilal/Pì'inal evaluation. It is necessary that the objects or classes belong to some recognized (but not necessarily named) higher-order class if the distinction is to apply. In this sense ranking logically presupposes classification. For example, cannoneers called bten kamaro in Zinacantan and b'antunyero in Chamula set off hand cannons and skyrockets to mark important stages in ritual. For each ceremony there are two cannoneers, one bankilal and the other 'i i'inal. Whenever fireworks are required in a Zinacanteco ceremony, the cannoneers explode two cannons followed by several rockets. The first cannon to be set off is called bankilal and the second is called 'id'inal. The bankilal cannoneer sets off the first cannon; his 'i $i$ 'inal partner sets off the second. Cannoneers in Chamula are more specialized in function: the bankilal cannoneers sets off cannons while the 'id'inal is shooting off skyrockets. Within the covert category "fireworks" cannons are bankilal and skyrockets are 'id'inal. The class "cannon" is a subclass of the higher-order class "fireworks", which includes also "skyrockets". Zinacantecos and Chamulas thus differ as to which level of the taxonomy they apply the bankilal/'ic'inal distinction. Moreover, Chamulas rank objects which do not share a lexical label in terms of bankilal/'ic'inal while Zinacantecos here restrict their evaluation to objects which have the same lexical label.

A general principle that the inhabitants of Zinacantan, Chamula, and Chenalho seem to follow is that the levels of a taxonomy should be kept separate when the bankilal/'ic'inal ranking is applied. For example, in Zinacantan the terms used to refer to mayordomos are compound proper names composed of the word martomo ("mayordomo") + the name of the saint sponsored by that mayordomo +the term bankilal or the term 'ic'inal, whichever is appropriate. When asked to rank an alferez in terms of a mayordomo, most informants respond that the terms bankilal and 'i\&'inal are appropriate for ranking mayordomos or alfereces, but not individual mayordomos in terms of individual alfereces. On the other hand, informants are 
quite willing to rank the class of alfereces against the class of mayordomos because they belong to the higher-order class "religious cargoholder" (hpas 'abteletik). Therefore, in applying the bankilal/ 'i i'inal distinction, it is always necessary to keep taxonomic levels straight, to avoid confusing a class with one of its members.

We may conclude that if two objects or classes of objects may be ranked in terms of the bankilal/'ic'inal contrast, then it means that they are imbedded in some folk taxonomy as members of some higher-order class. Conversely, if two objects or classes of objects may not be ranked in terms of the bankilal/Pie'inal contrast, but belong to a domain which permits such evaluation, then it means either that the objects or classes in question belong to different taxonomies, or that they belong to different classes within the same taxonomy.

\section{BIBLIOGRAPHY}

CANCIAN, F.

1965 Economics and prestige in a Maya community: the religious cargo system in Zinacantan. Stanford: Stanford Univ. Press.

Gossen, G. H.

1970 Time and space in Chamula oral tradition. Unpublished Ph. D. dissertation, Harvard University.

GuITERAS-HoLmES, C.

1946 Informe de San Pedro Chenalbó. Microfilm Collection of Ma. nuscripts on Middle American Cultural Anthropology, núm. 14. University of Chicago.

1961 Perils of the soult: the world view of a Tzotzil indian. Glencoe: The Free Press.

REMESAL, A.

1964 Historia general de las Indias occidentales y particulares de la gobernación de Chiapas y Guatemala. 2 vols. Madrid.

VoGT, E. Z.

1965 Zinacanteco "souls". Man (N.S.) 29, 33-35.

1969 Zinacantan: a Maya community in the bighlands of Chiapas. Cambridge: Harvard Univ. Press.

WASSBRSTROM, R. F.

1970 Our lady of the salt. Unpublished A. B. Honors thesis, Harvard University.

ZABALA, M. T.

1961 "Instituciones políticas y religiosas de Zinacantán." Estudios de Cultura Maya, 1, 147-158. México, UNAM. 
TABLE 1

Parameters of Bankilal/? $\phi^{\prime}$ inal Ranking

\begin{tabular}{|c|c|c|}
\hline \multirow[b]{3}{*}{ Parameter } & \multicolumn{2}{|l|}{ Zinacantan } \\
\hline & \multicolumn{2}{|c|}{ Values } \\
\hline & Bankilal & ${ }^{2} I_{\phi}^{\prime}$ 'inal \\
\hline $\begin{array}{l}\text { size } \\
\text { sex } \\
\text { height } \\
\text { distance } \\
\text { number } \\
\text { age } \\
\text { origin } \\
\text { species } \\
\text { elevation } \\
\text { time } \\
\text { birth order } \\
\text { status } \\
\text { knowledge } \\
\text { intelligence } \\
\text { walking order } \\
\text { ethnic group } \\
\text { direction }\end{array}$ & $\begin{array}{l}\text { bigger } \\
\text { male } \\
\text { upper } \\
\text { near } \\
\text { many } \\
\text { old } \\
\text { older } \\
\text { God-made } \\
\text { natural } \\
\text { human } \\
\text { highland } \\
\text { earlier } \\
\text { first } \\
\text { senior } \\
\text { more knowledgeable } \\
\text { clever } \\
\text { first (informal) } \\
\text { last (formal) } \\
\text { Ladino } \\
\text { east } \\
\text { south } \\
\text { right } \\
\text { head } \\
\text { center } \\
\text { gives commands }\end{array}$ & $\begin{array}{l}\text { smaller } \\
\text { female } \\
\text { lower } \\
\text { far } \\
\text { few (rare) } \\
\text { new } \\
\text { younger } \\
\text { man-made } \\
\text { cultural } \\
\text { animal } \\
\text { lowland } \\
\text { later } \\
\text { last } \\
\text { junior } \\
\text { less knowledgeable } \\
\text { stupid } \\
\text { last (informal) } \\
\text { first (formal) } \\
\text { Indian } \\
\text { west } \\
\text { north } \\
\text { left } \\
\text { foot } \\
\text { ends (edges, sides) } \\
\text { obeys commands }\end{array}$ \\
\hline
\end{tabular}

Chamula

\begin{tabular}{lll}
\hline & \multicolumn{2}{c}{ Values } \\
\cline { 2 - 3 } Parameter & Bankilal & If $\phi^{\prime}$ inal \\
\hline size & bigger & smaller \\
sex & male & female \\
height & upper & lower \\
distance & near & far \\
& Chamula & Zinacantan
\end{tabular}


TABLE 1 Continued (2)

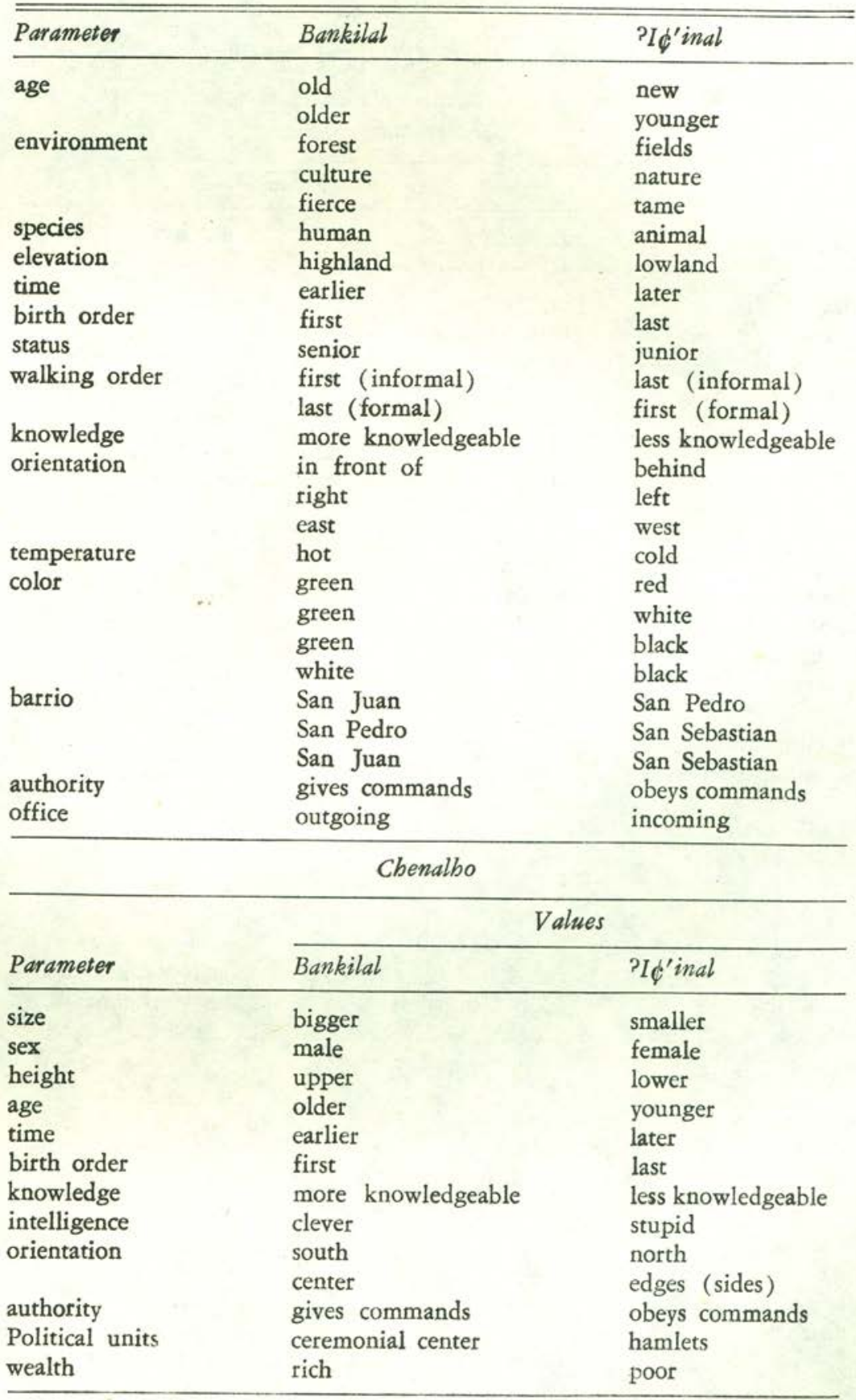


TABLE 2

RANKING OF SACRED PLACES (ZINACANTAN)

\begin{tabular}{|c|c|c|c|c|c|}
\hline Sacred Place & orig & $n$ beight & elevation s & $x$ si & \\
\hline 1. bankilal muk'ta vie & God-made & summit & highland & $\mathrm{m}$ & large \\
\hline 2. san kištoval & " & $"$ & ", & $"$ & smaller \\
\hline 3. kalvario & $"$ & $"$ & $"$ & $"$ & $"$ \\
\hline 4. sisil vik & $"$ & $"$ & $"$ & f & larger \\
\hline 5. $m u \check{S} u l v i_{\phi}$ & $"$ & $"$ & $"$ & $"$ & smaller \\
\hline 6. ya?abvil (cross) & $"$ & below & $"$ & $"$ & \\
\hline 7. ninab čilo? (cross) & $"$ & $"$ & $"$ & $"$ & \\
\hline 8. Pisak'tik (cross) & $"$ & $"$ & lower & $\mathrm{m}$ & \\
\hline 9. č́ul ton (cross) & $"$ & $"$ & $"$ & f & \\
\hline 10. bč'ulme?tik & $"$ & summit & " & $"$ & \\
\hline 11. sisil vid & $"$ & base & highland & $"$ & \\
\hline 12. $m u \check{\mathrm{S} u l} v i \phi$ & $"$ & $"$ & " & $"$ & smaller \\
\hline 13. bč'ulme?tik & $"$ & $"$ & lower & $"$ & \\
\hline 14. San Lorenzo church & man-made & & highland & $\mathrm{m}$ & \\
\hline 15. San Sebastian church & $"$ & & $"$ & $"$ & . smaller \\
\hline 16. Esquipulas chapel & $"$ & & $"$ & $"$ & $"$ \\
\hline
\end{tabular}

TABLE 3

CONCEPTUAL DIFFERENCES IN RANKING SERIES

\begin{tabular}{|c|c|c|}
\hline $\begin{array}{l}\text { Chamula } \\
\text { Chenalbo }\end{array}$ & Zinacantan & $\begin{array}{l}\text { Zinacantan } \\
\text { Chamula }\end{array}$ \\
\hline bankilal & bankilal & bankilal \\
\hline${ }^{2} \phi_{\phi}^{\prime}$ inal & 2 & 2 \\
\hline${ }^{i} \phi_{\phi}^{\prime}$ inal & 3 & 3 \\
\hline${ } i_{\phi}^{\prime}$ inal & 4 & 4 \\
\hline${ }^{i} \phi^{\prime}$ inal & - & - \\
\hline$P_{i} \phi^{\prime}$ inal & - & - \\
\hline$P_{i} \phi^{\prime}$ inal & • & - \\
\hline Pis'inal & ${ }^{2} i_{\phi}^{\prime}$ inal & $\mathrm{n}$ \\
\hline
\end{tabular}




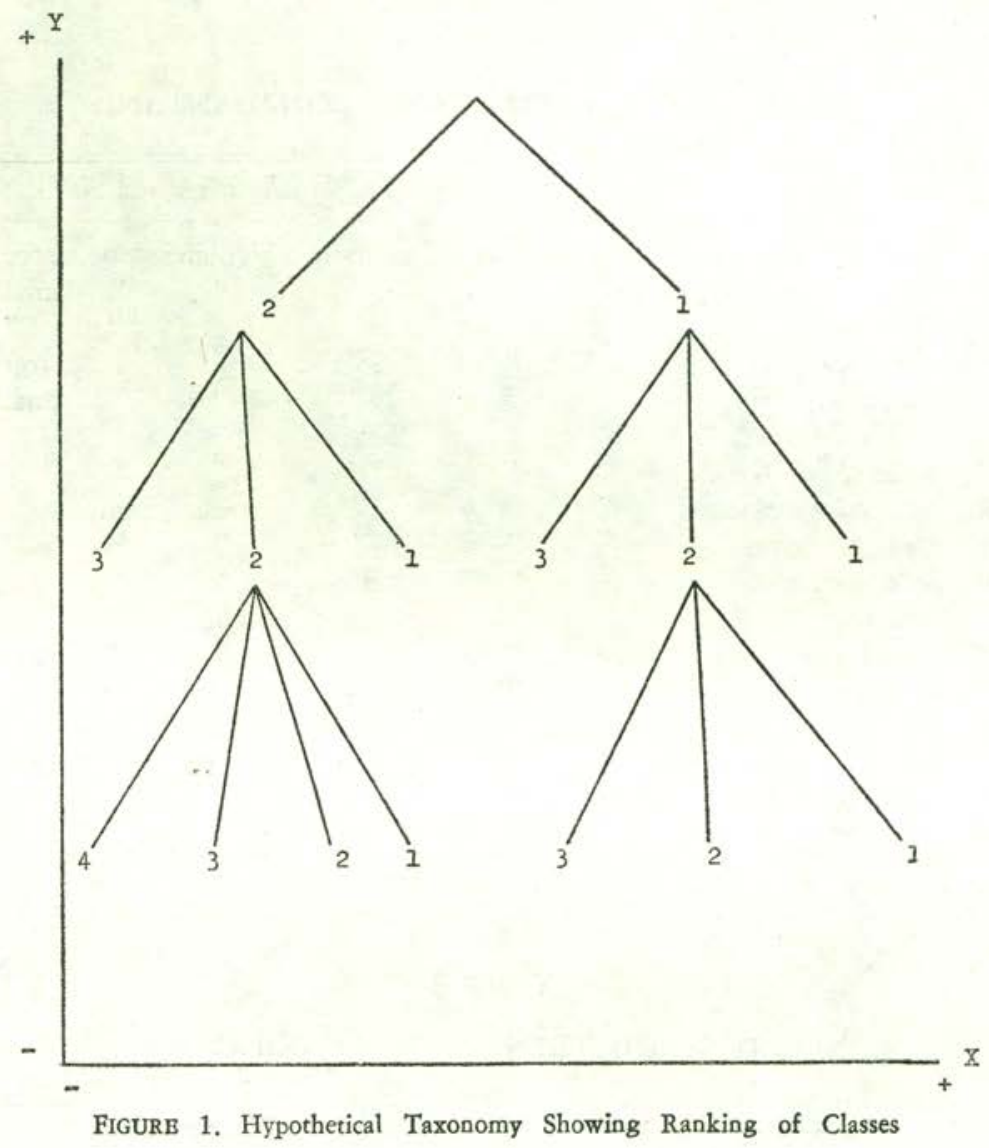




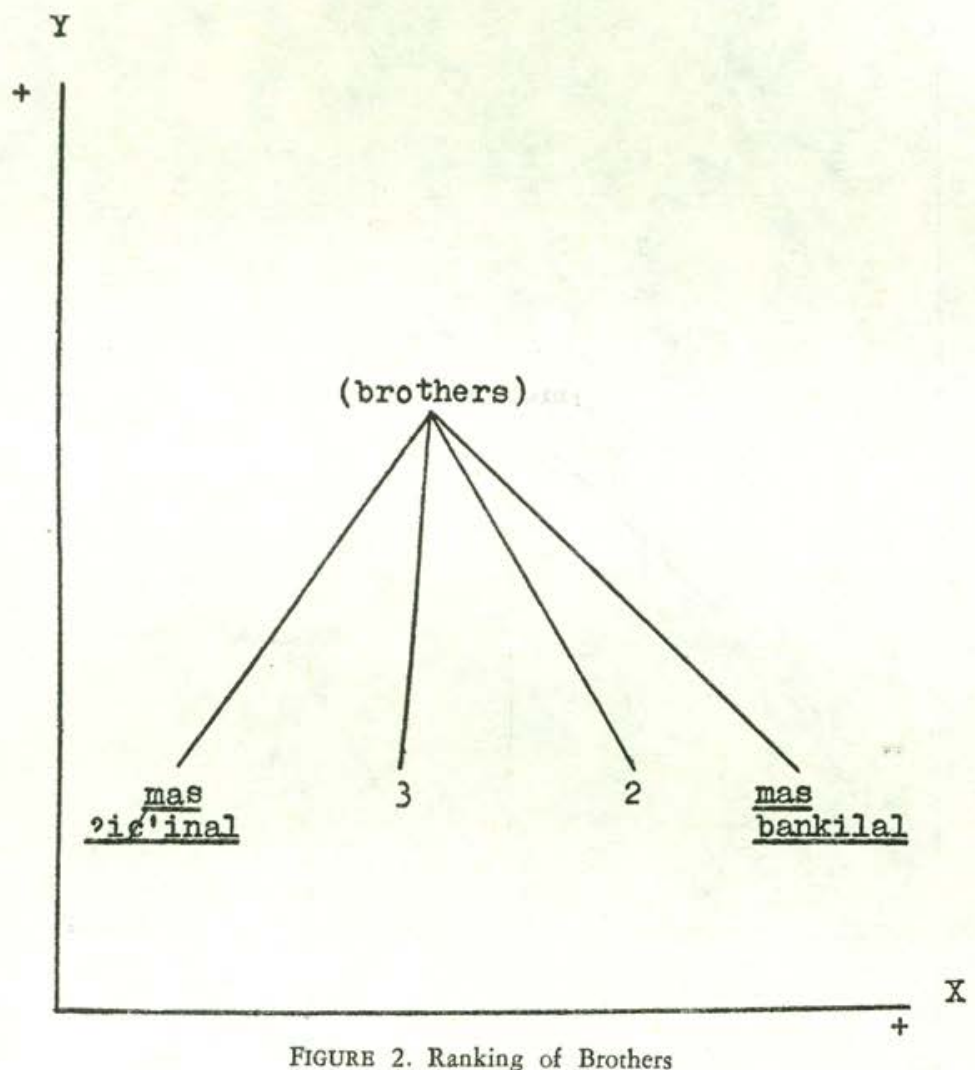




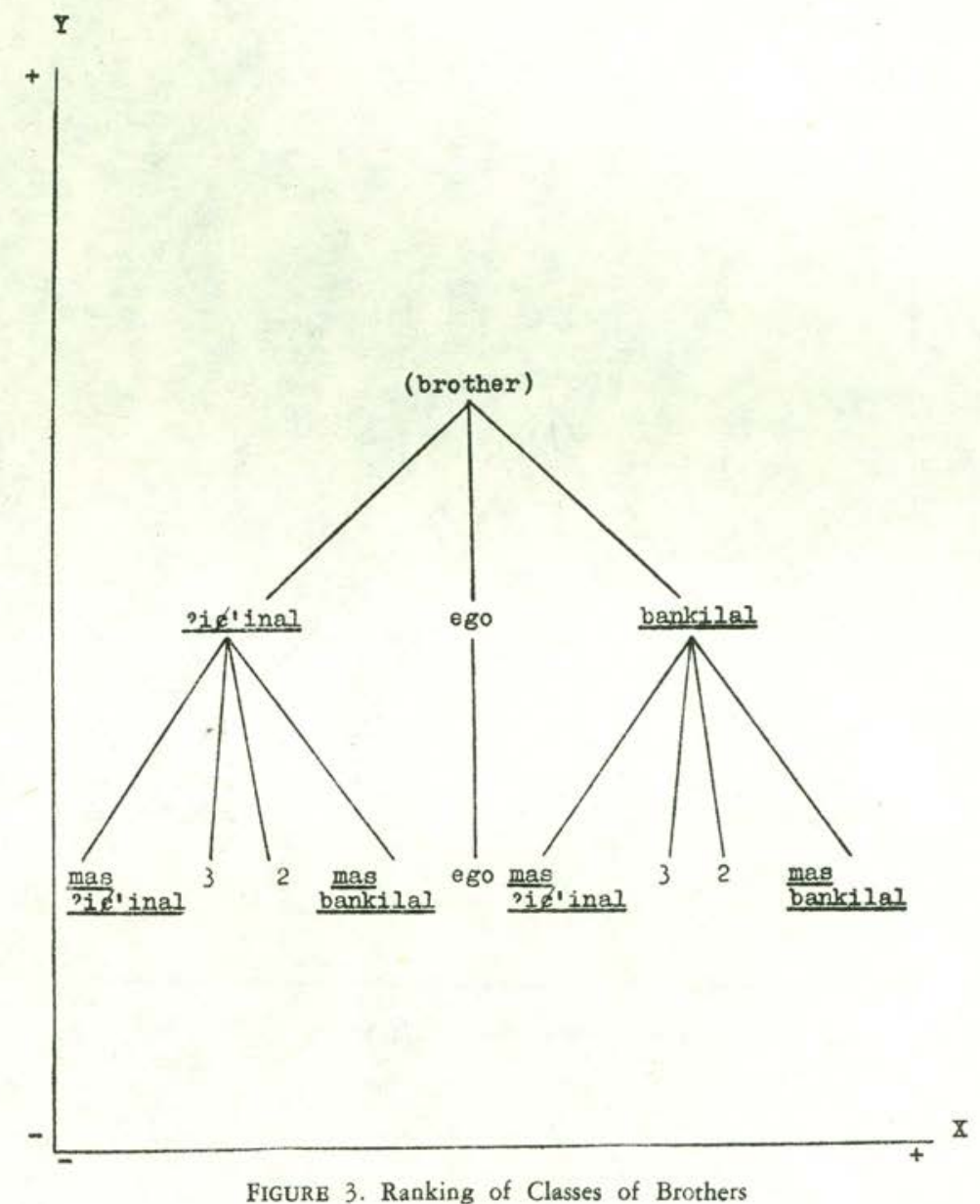




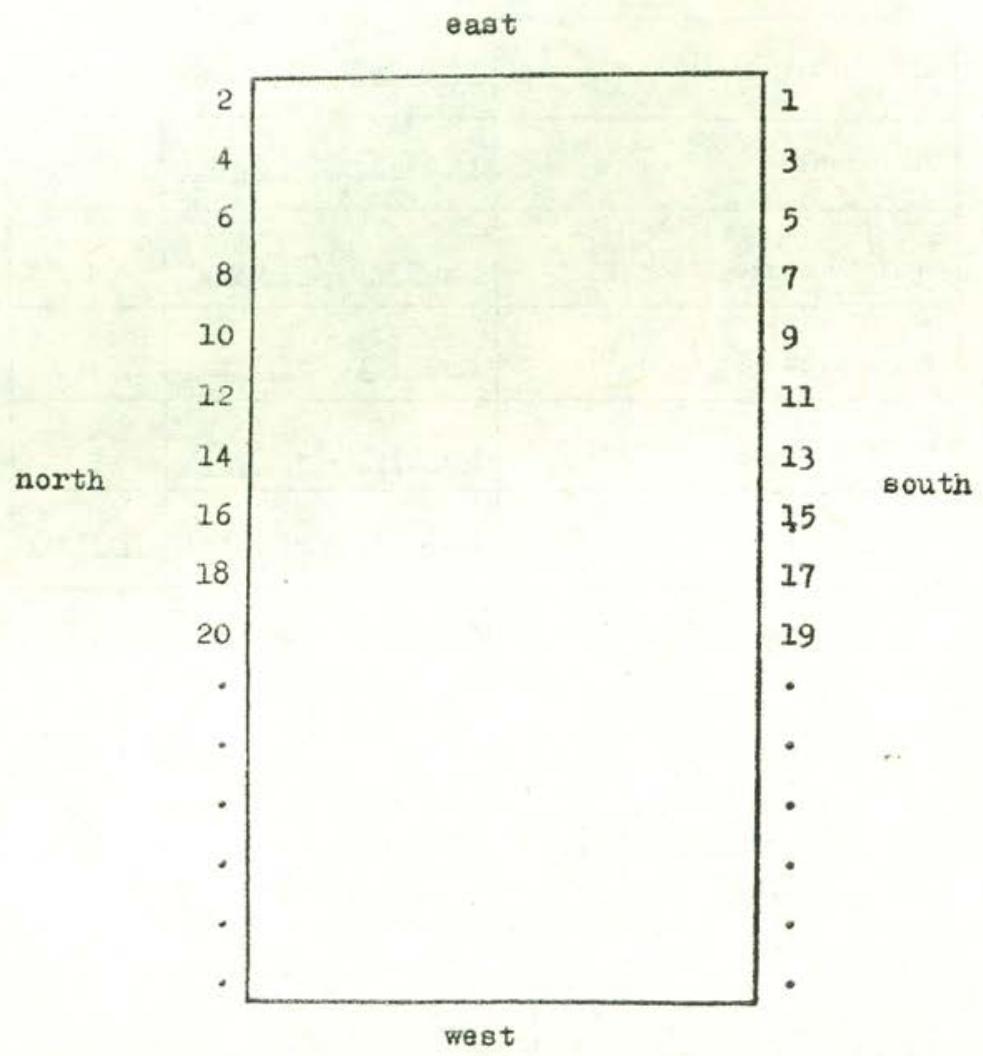

FIgURE 4. Seating Order at a Ritual Meal (Zinacantan, Chamula) 


\begin{tabular}{|c|c|c|}
\hline Virgen del Rosario & bankilal - pikjinal & bankilal \\
\hline Sacramento & bankilal - 2id'inal & 2 \\
\hline Santo Domingo & bankilal - 2ik'inal & 3 \\
\hline Santa Cruz & bankilal - 2idinal & 4 \\
\hline San Sebastian & bankilal - 2i\&'inal & 5 \\
\hline San Antonio & bankilal - 2i E'inal & ideinal \\
\hline
\end{tabular}

FIGURB 5. Ranking of Mayordomos (Zinacantan)

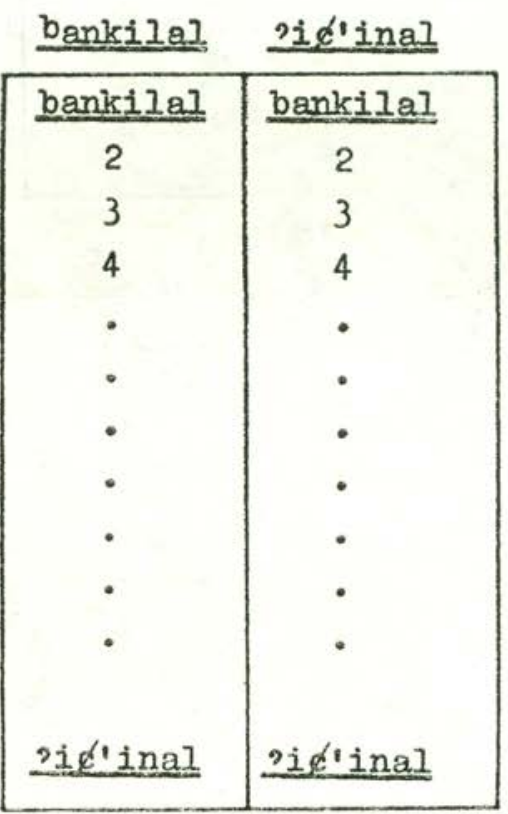

FIGURE 6. Ranking of Shamans (Zinacantan) 


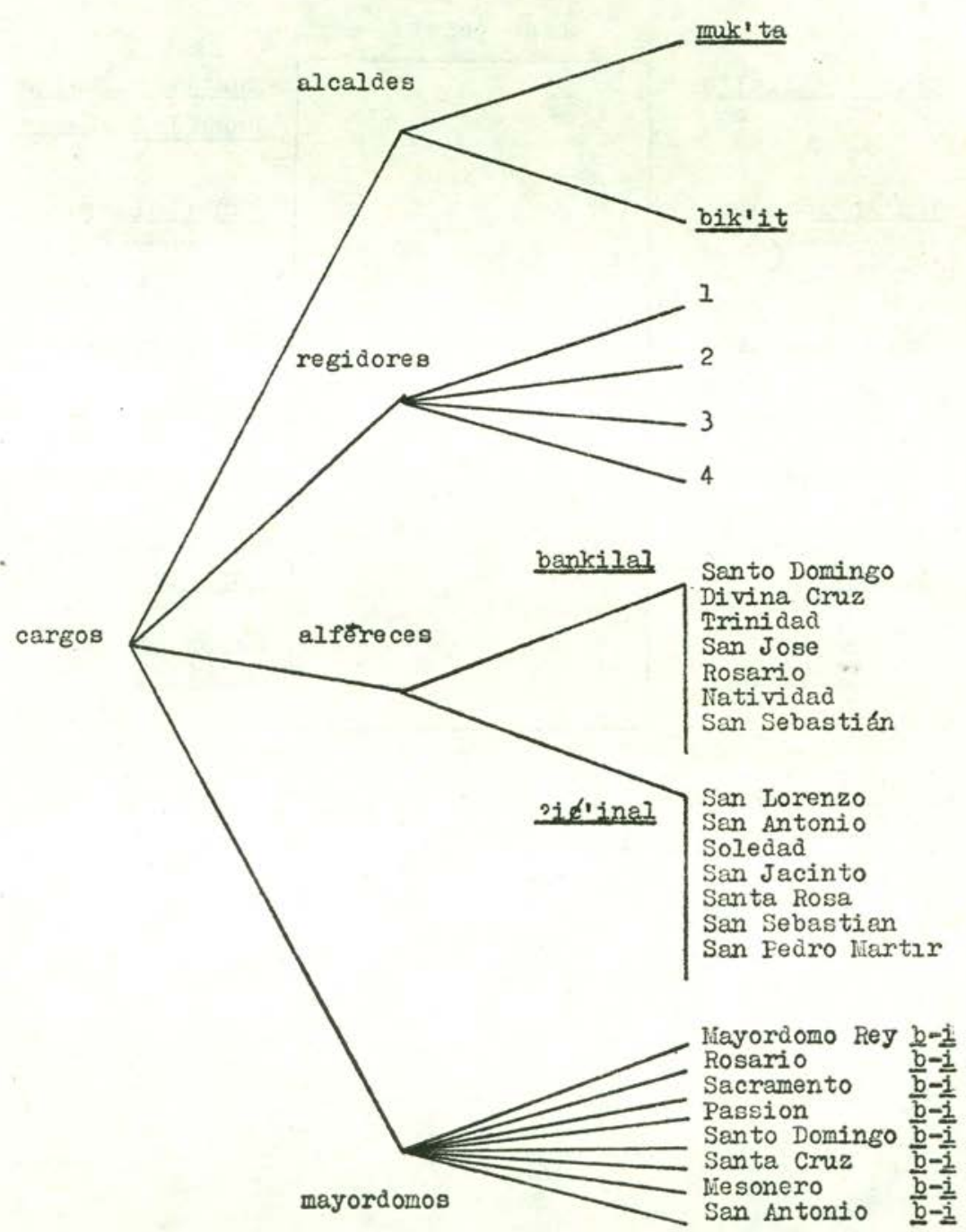

FIGURE 7. Ranking of Religicus Cargoholders (Zinacantan) 


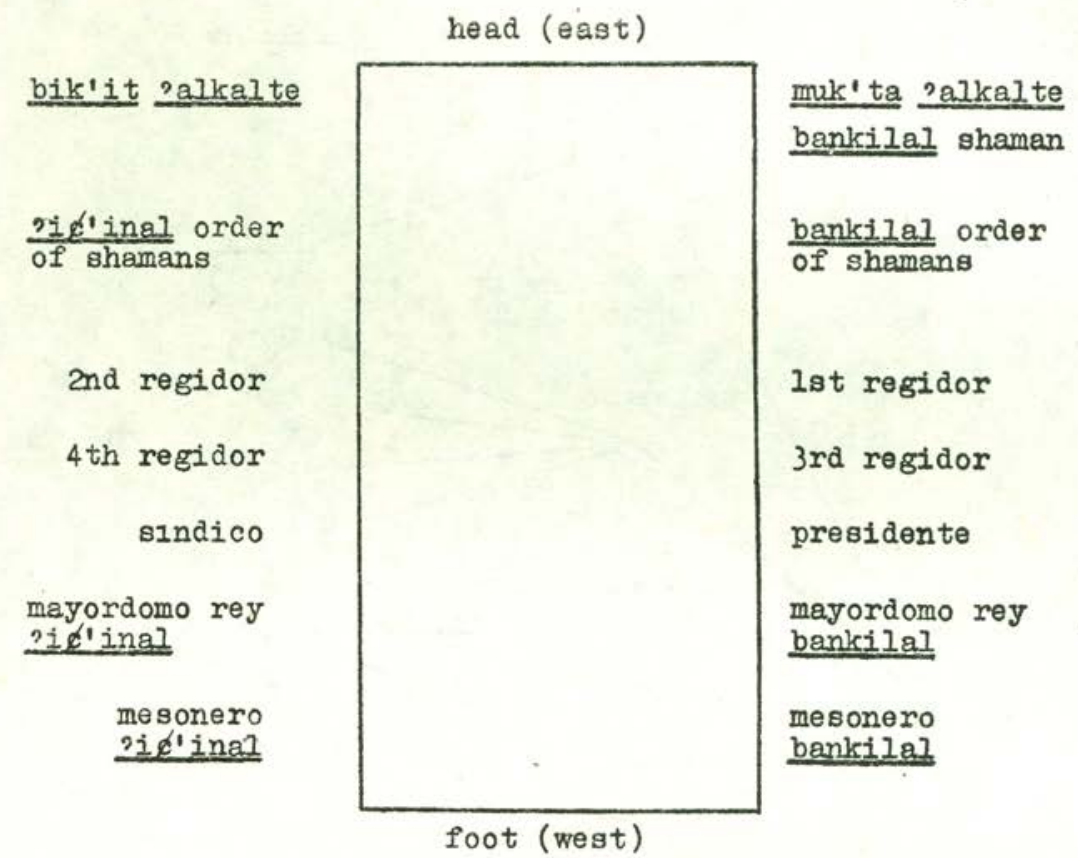

FIGURE 8. Seating of Shamans, Civil and Religious Officials during Summer Solstice (Zinacantan) 


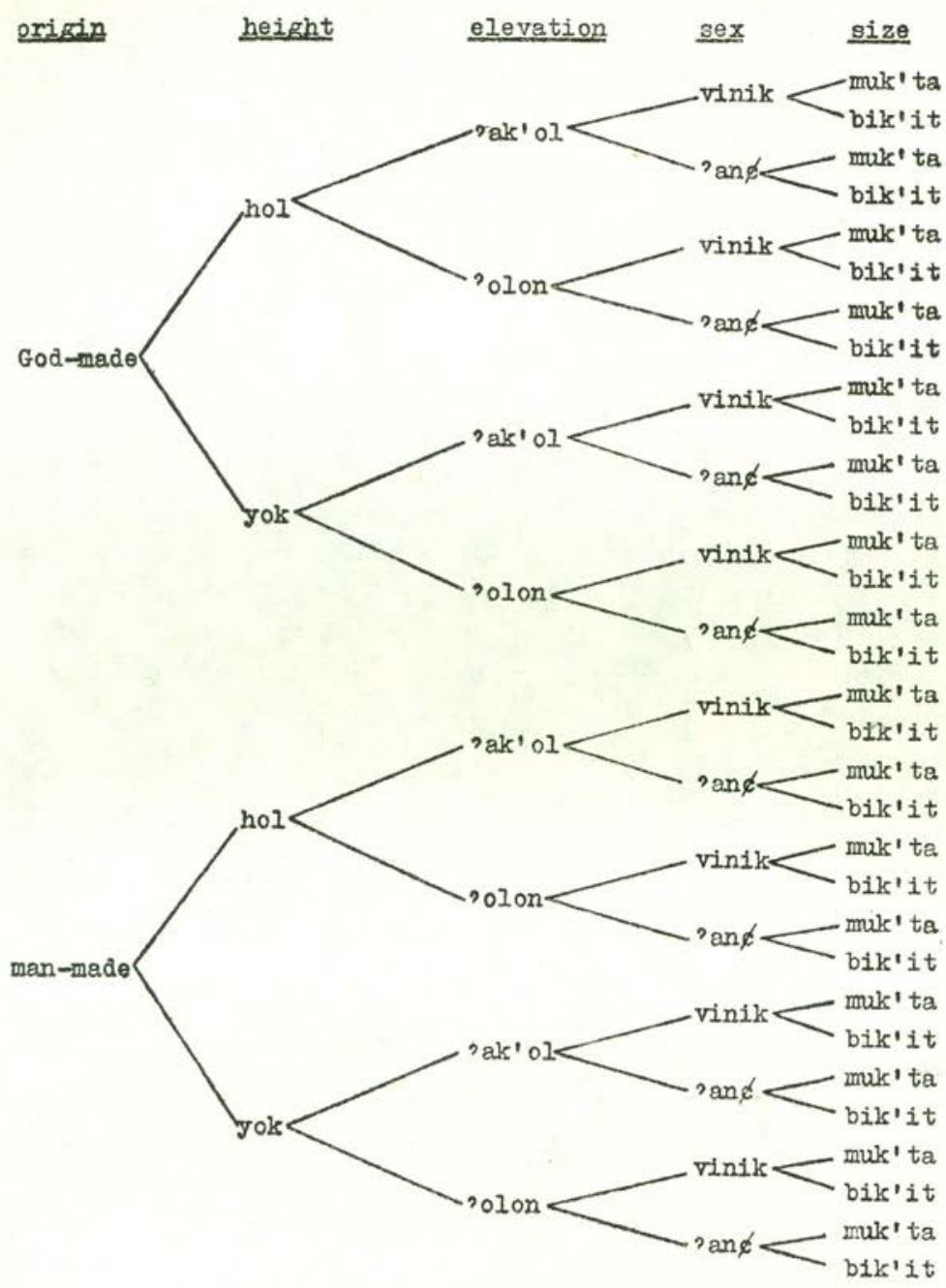

FIGURE 9. Ranking of Parameters (Zinacantan) 